\title{
A BIOGRAPHICAL APPROACH TO THE ETHNOGEOLOGY OF LATE PREHISTORIC PORTUGAL
}

\author{
UN ENFOQUE BIOGRÁFICO PARA LA ETNOGEOLOGÍA DE LA PREHISTORIA FINAL EN \\ PORTUGAL
}

KATINA T. LILLIOS $(*)$

\begin{abstract}
In this paper, I explore the relationship between an artifact's biography and the raw material from which it was made. Specifically, I discuss the biographies of groundstone tools from five Late Neolithic and Chalcolithic (3500-2000 BC) sites in lowland Portugal.An analysis of the formal and material characteristics of tools (totalling over 1300) from these sites indicates that the raw material from which a tool was made not only constrained the form and function of that tool, but also determined, to a large extent, whether that tool would be recycled and the context (settlement $v s$. burial) in which that tool would be ultimately deposited. I suggest that both the material properties and the socio-symbolic associations of different raw materials might explain the biographies of the artifacts from which they were made.
\end{abstract}

\section{RESUMEN}

En este trabajo, exploro las relaciones entre la biografía del artefacto y la materia prima a partir de la cual se hizo. Específicamente discuto las biografías de los útiles de piedra pulimentada de cinco sitios del Neolítico Final y Calcolítico (3500-2000 AC) de las tierras bajas portuguesas. El análisis de las características formales y materiales de los útiles (unos 1300 en total) de estos sitios indica que la materia prima a partir de la cual se hizo un utensilio no sólo limitó su forma y función, sino que también determinó, en gran medida, si sería reciclado y el contexto (poblado vs enterramiento) en el que sería finalmente depositado. Sugiero que tanto las propiedades materiales como las asociaciones socio-simbólicas de las diferentes materias

(*) Department of Anthropology and Sociology. Ripon College. Ripon, Wisconsin 54971. United States of America. Email: LilliosK@ ripon.edu.

El artículo fue remitido en su versión final el 23-XI-99. primas a partir de las cuales se hicieron los artefactos pueden explicar sus biografias.

Key words: Geoarchaeology. Polished stone tools. Neolithic. Chalcolithic. Portugal. Artifact biographies.

Palabras clave: Geoarqueología. Utiles de piedra pulimentada. Neolítico. Calcolítico. Portugal. Biografías de los artefactos.

\section{INTRODUCTION}

Objects, like people, have life histories. And, like the lives of people, the life histories of objects are not entirely random. They are, in fact, culturally and socially patterned. The life histories of some classes of objects can be rather short, such as those of expedient stone tools produced and used by one individual and discarded after one use episode, or they can be long, as in the case of valued heirlooms produced by one individual, used by another, and passed down from one generation to the next for hundreds of years. From their manufacture and distribution to their consumption and ultimate disposal, the biographies of objects reflect, as well as constrain, the symbolically constituted lives of human beings. In reconstructing and interpreting the trajectories that objects take in their lives, archaeologists, art historians, and scholars of material culture studies have been able to gain important insights into the value and meaning of ancient objects to their ancient owners (Schiffer, 1976; Appadurai, 1986; Kopytoff, 1986; Rawson, 1993; Skeates, 1995; Lillios, 1999a, b).

During the Late Neolithic and Chalcolithic of Portugal (3500-2000 BC), a period during which 
social inequalities become apparent in the material record (Gilman, 1987; Chapman, 1990), a variety of artifact types were produced, circulated, and differentially distributed between individuals and communities. These objects include decorated ceramics, such as Beakers, copper tools and weaponry, flint arrowheads, blades, and halberds, engraved slate plaques, and polished stone tools. Analyses of these objects have generally taken the form of formal and typological studies (Harrison, 1977; Kunst, 1987; Uerpmann, 1994; Valera, 1997: 63-140; Forenbaher, 1998, 1999), chemical characterizations (Lillios, 1997; Read et alii, 1997), and explorations into the possible symbolic content of their design and iconography (Lisboa, 1985). These analyses have provided insights into the sourcing of raw materials, the technical processes involved in the production of the different artifact classes, the socio-economic organization of production and distribution, and the function and meaning of the artifacts in question. In these traditional approaches to material culture, however, material culture is viewed statically - frozen in time. These approaches tend to neglect the reality that all objects move through a life cycle, from birth (manufacture), maturity (use), and death (disposal) and their function and meaning may very well have shifted throughout this life cycle as they was used by different individuals or groups, in the presence of different individuals and groups, and in different social or ritual contexts. New research questions emerge with this biographic approach. Why were some objects within an artifact class circulated for significantly different lengths of time than others? Under what social, political, or economic conditions do the life histories of artifact classes change? Or, as I will consider in this paper: what is the relationship between the 'birthplace', or the source of a raw material, and its 'deathplace', or disposal context?

Specifically, I will explore the relationship between the raw material from which polished stone tools were made and the life histories of these tools during the Late Neolithic and Chalcolithic of Portugal. Manufactured from a wide variety of raw materials, including local and non-local rocks, and made into axes, adzes, hammers, chisels, and gouges, these tools were used to clear forests, till fields, carve wood, and defend territory and, as such, were critical to the livelihood of agrarian communities. Polished stone tools often entered the archaeological record as discarded used tools in settlements, sometimes in the hundreds. In addition, polished, but unused and often large stone tools, particularly axes and adzes, were typical burial offerings. Polished stone tools were, thus, not only highly polymorphic but were also likely polysemic and must have played an important role in the political economy as well as ritual spheres of cultural life during the Late Neolithic and Chalcolithic of lowland Portugal. It is probably safe to say that natural as well as social landscapes of late Portuguese prehistory were dramatically transformed through the acquisition, use, exchange, and disposal of polished stone tools.

\section{SITES AND METHODS}

A total of approximately 1300 tools from five Late Neolithic and Chalcolithic sites were analyzed for this study. These sites are the settlements of Leceia, Zambujal, and Pragança, and the burial sites of Cova da Moura and Algar do Bom Santo (Fig. 1). These sites were selected for analysis because they were used or occupied over approximately the same time periods, because they are located within the same prehistoric culture area (within $60 \mathrm{~km}$ of each other), and because their associated artifacts are similar in size and content. Thus, their assemblages can be viewed as roughly comparable.

The site of Zambujal is a walled hilltop settlement that encompasses an area of approximately 2.0

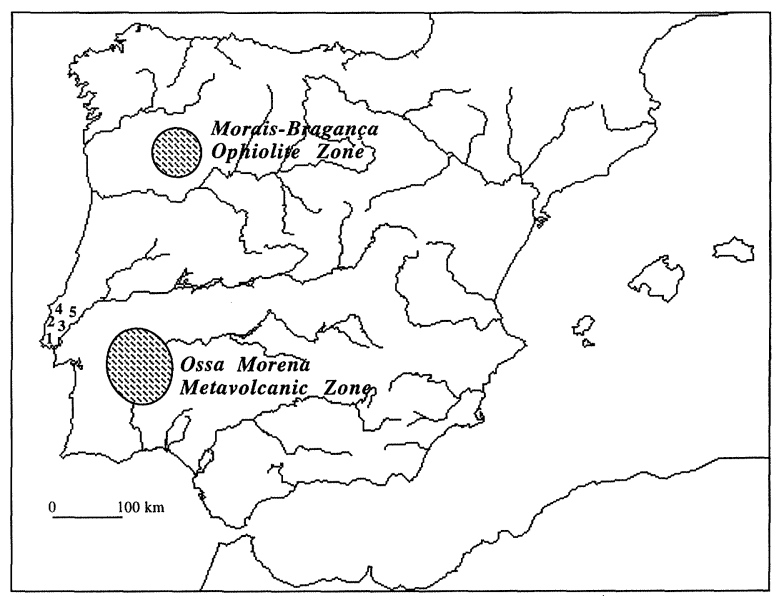

Fig. 1. Map of sites studied and geographic distribution of amphibolite sources in western Iberia. Site Numbers: 1. Leceia, 2. Zambujal, 3. Cova da Moura, 4. Pragança, 5. Algar do Bom Santo. Sources of geological information: Quesada and Munha, 1990; Ribeiro et alii, 1990). 
ha and overlooks the ribeira de Pedrulhos, in west-central Portugal. In addition to a broad range of ceramics, lithics, and metal goods, the remains of copper-working, textile production, and pottery manufacturing facilities have been recovered at the site. Zambujal was first noted in 1932 by Trindade (Kunst, 1993: 47-50), excavated in the 1940s by Trindade, excavated again by Trindade and Belo from 1959-1961, and from 1964 to 1973 by Sangmeister, Schubart, and Trindade (Sangmeister and Schubart, 1981). Excavations at Zambujal were resumed in 1994 by the GermanArchaeological Institute in Madrid. Radiocarbon dates from the site range between $4200 \pm 40$ B.P. (GrN-7009) and 3530 \pm 65 B.P. (KN-I.115) (Sangmeister and Schubart, 1981: 264-266); these correspond to the site's Late Neolithic through Late Chalcolithic phases. The artifacts recovered from excavations are housed primarily in the Museu Municipal deTorres Vedras. Over 500 polished stone tools were recovered at the site.

Like Zambujal, Leceia is also a walled hilltop settlement (elev. $100 \mathrm{~m}$ ). It extends over approximately 1.0 ha and overlooks the ribeira da Barcarena. Thirty-five radiocarbon dates have been obtained from the site, which range between $4630 \pm 45$ B.P. (ICEN 738) and $3660 \pm 50$ B.P. (ICEN 1219) (Cardoso and Soares, 1996). Culturally, the site was occupied during the Late Neolithic, and Early and Late Chalcolithic phases, like Zambujal. From an historiographic perspective, Leceia is also important as it was one of the first Chalcolithic sites to be excavated in Portugal. Early excavations were carried out in the 1860 s and 1870 s by Ribeiro (1878), in the beginning of the 20th century by Leite de Vasconcelos (1917), and between the 1920s-1950s by Roseiro, Álvaro de Brée, and Fontes (Fontes, 1955). Systematic excavations were conducted under the direction of Cardoso beginning in 1983 and continuing into the present (Cardoso, 1982, 1989, 1994a, b; Cardoso et alii, 1983-1984; Cardoso and Soares, 1996). The material from the earlier excavations is largely housed in the Museu Nacional de Arqueologia, in Lisbon. Approximately 340 polished stone tools have been recovered from Leceia.

The walled settlement of Pragança, situated at an elevation of $334 \mathrm{~m}$, has two radiocarbon dates of $4050 \pm 60$ B.P. (ICEN 57) and $4120 \pm 50$ B.P. (ICEN 573) (Gonçalves, 1990-1992). The site was discovered by Leite de Vasconcelos in 1893, excavated in the 1930 s by Trindade, and re-excavated from 1988 to 1990 by Gonçalves. The artifacts from
Pragança, including about 370 polished stone tools, are housed in the Museu Nacional de Arqueologia in Lisbon.

Cova da Moura is a cave burial situated at an elevation of $75 \mathrm{~m}$ and overlooks the Rio Sizandro, approximately $4 \mathrm{~km}$ from Zambujal (Kunst and Trindade, 1990-1991: Abb. 1). The remains of 90 individuals, including adults and children, were recovered from the site. No radiocarbon dates were obtained although its assemblage, which includes Bell Beakers and slate plaques, places it in the same cultural phases (Late Neolithic through Chalcolithic) as the three settlements (Spindler, 1981). Cova da Moura was first noted and excavated in 1932 by Trindade and Belo, and again excavated in 1961 by Belo et alii (1961; Gallay and Spindler, 1970; Spindler, 1981). The artifacts from Cova da Moura are presently housed in the Museu Municipal de Torres Vedras; these include approximately 65 polished stone tools.

Finally, analyses were also carried out on the polished stone material from the burial of Algar do Bom Santo. This site, a recently discovered (1993) and extensive (285 m2) cave burial, is located on the slopes of the Serra de Montejunto, a few kilometers from the settlement of Pragança. The remains of at least 121 individuals, with their grave goods (including over 21 polished stone tools), have been recovered at the site. Six radiocarbon dates were obtained on skeletal material; the five dates that were considered to be the most reliable range from $4860 \pm 100$ B.P. (OxA-5513) to $4430 \pm 50$ B.P. (Beta-120047). These dates, in addition to the artifactual assemblages, situate the site squarely within the Late Neolithic (Duarte, 1998).

Each polished stone artifact from these sites was examined by the project geologists, Howard Snyder and Caroline Read, for its material and formal characteristics. Those characteristics that specifically address aspects of the life history of the tools, and that are discussed in this paper, include:

- Raw material (hand lens [10x] and stereoscopic microscope).

- Stage of production represented by artifact.

- Class of artifact.

- Context of artifact deposition.

\section{THE LIVES OF STONES}

Late prehistoric communities in the lowlands used polished stone tools made from a wide range 
of raw materials. Some of these raw materials were locally available (basalt, dolerite, siltstone, e.g.), while others were only found at some distance from the sites (amphibolite, e.g.). Although twelve classes of stone were used at these five sites, only four were regularly used (Tabl. 1). That these four stone types account for the vast majority of the tools at these sites suggests that late prehistoric craftsmen had identified these classes of stones as eminently suitable for polished stone tools and continued to

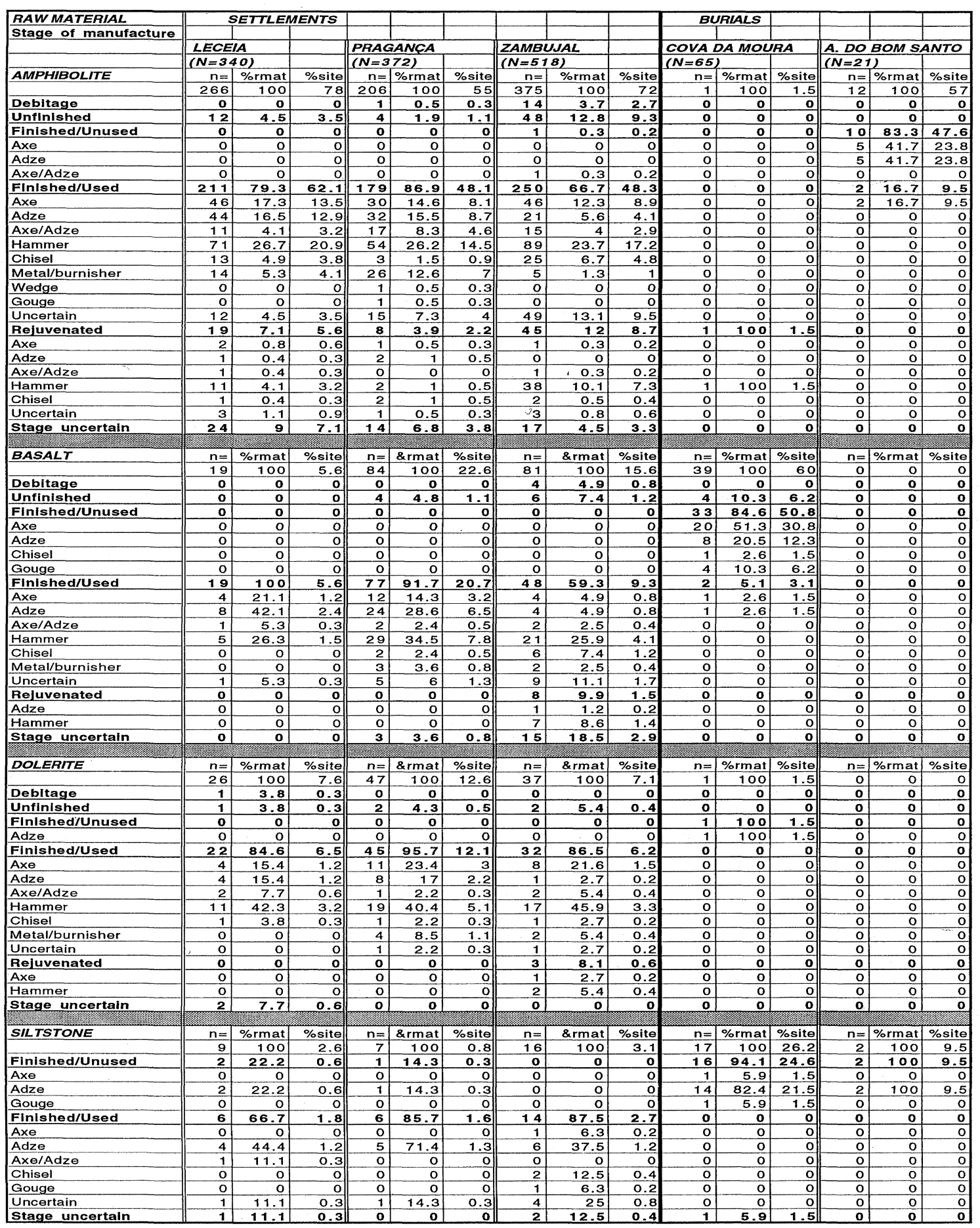

Tab. 1. Raw data. 
use these stones for a considerable period of time. The remaining eight rock types were so rarely utilized that they do not allow us to make any generalizations; these include aplite, miscellaneous volcanics, chert, limestone, granite, serpentinite, and slate. Their rarity, in itself, probably reflects some combination of their having been difficult to acquire by late prehistoric communities and their having been considered inappropriate for technological, social, or ideological reasons.

\section{Siltstone}

Siltstone is available locally, in the Lisbon and Setúbal peninsulas (Carta Geológica de Portugal 1992). Siltstone tools were sometimes found in both settlement and burial contexts. They are, however, generally more abundant, relative to other raw materials, in burial contexts; this may be due to the stone's softness and unsuitability for making durable 'working' tools destined for settlement contexts.

No unfinished tools made from siltstone were found at any of the sites. Tools were considered unfinished if they were minimally polished, showed no signs of use, and were trapezoidal in form. This pattern may suggest that siltstone tools were traded as finished tools, made to order, or that any unfinished tools were taken away by the sites' inhabitants when the sites were abandoned. That siltstone tools, as finished tools, were almost always made into adzes suggests the possibility that the trade of siltstone roughouts (which could be made into any number of forms) did not make sense to late prehistoric groups (who seemed to use the stone largely to make adzes).

A few finished and unused siltstone tools were found at Leceia and Pragança, while at Cova da Moura and Algar do Bom Santo, all the siltstone tools were finished and unused. The finished and unused tools at the settlements may have been intended as burial offerings or perhaps simply had not yet been put to use in a 'living' context.

Of the finished and used tools of siltstone, none were found in the burials and only a few were found in settlements. Siltstone tools were never found rejuvenated. It is likely that the weaknesses of siltstone as a durable stone were recognized by late prehistoric groups, and its use was considered primarily as the raw material for burial offerings - rarely actually designed to cut, till, or carve.

\section{Dolerite (including altered dolerite)}

Sources of dolerite are found locally to the sites as well as throughout the southern half of Portugal (Carta Geológica de Portugal, 1992). No source characterization studies have been carried out on the Portuguese dolerites.

Tools made of dolerite were regularly found in settlement contexts. Some of these were unfinished tools, which suggests some exchange or direct acquisition of dolerite blanks. No finished and unused dolerite tools were, however, found.

A number of finished and used dolerite tools were found on the settlements. Most of these tools were made into hammers. The use of dolerite to principally make hammers, rather than axes or adzes, is likely due to an -emic recognition of the coarse- grained crystalline structure of dolerite, which renders dolerite suitable for hard percussive activities.

Rejuvenated tools made of dolerites are rare in settlement contexts. This was also likely due to the fact that dolerites were locally available, and once a tool was worn down, it was probably relatively easy to procure more of the raw material.

Dolerite tools are rarely found in burial contexts, in contrast to their occurrence in settlements. Only one finished and unused tool, an adze, was found at Cova da Moura; none were found at Algar do Bom Santo. Why dolerite tools were so rarely included in burials is difficult to explain. Dolerite was certainly not an exotic stone and, thus, its absence in burials cannot be due to the reluctance of ancient peoples to dispose of a difficult-to-acquire stone. The best explanation for the near-absence of dolerite tools in burials may involve ideological reasons; Late Neolithic and Chalcolithic groups who buried their dead at Cova da Moura and Algar do Bom Santo may simply not have considered objects made from this raw material appropriate for burial offerings.

\section{Basalt (including altered basalt)}

Found regularly in lowland settlement contexts and, less regularly, in burial contexts are polished stone tools made of basalt. Basalts are found locally in the region of the five sites (within $20 \mathrm{~km}$ ) (Carta Geológica de Portugal, 1992). Source characterization studies for the purposes of identifying the origins of basalt tools have never, however, been undertaken. 
At the settlements of Pragança and Zambujal, tools made of basalts were second in abundance, next to amphibolite (considered below). At Leceia, however, basalt tools were significantly less common than at the other two sites. This is curious as Leceia is situated atop an outcrop of basalt. Perhaps this reflects the unsuitability of the local basalt for the purposes at hand. This may also suggest that the acquisition of polished stone tools was embedded in a fundamentally social exchange or prestige goods network in the Late Neolithic and Chalcolithic (rather than part of an economy based entirely on a least-cost/least-effort principal), and that tools made from the local basalts were traded out for tools made from other raw materials, such as amphibolite or dolerite.

Some unfinished basalt tools were recovered at Pragança and Zambujal, suggesting that basalt was acquired, at times at least, in the form of roughouts. There were no finished and unused pieces found at the settlements.

In their finished and used form in settlements, basalt tools were varied in form. They were principally made into axes, adzes, hammers, chisels, and burnishers. The fine-grained crystalline structure of the basalts made them particularly suitable for relatively durable cutting tools, a fact that seems to have been appreciated by ancient craftsmen.

Basalt tools found in the settlements rarely showed signs of rejuvenation. Because basalt was locally available or perhaps because roughouts could be acquired easily through exchange, it was probably not generally considered worthwhile to rework a broken or worn tool.

In the case of the two burials, significant differences occur in the use of basalts. At Cova da Moura, polished tools were more commonly made from basalt than any other raw material. These generally came in the form of axes, adzes, and gouges, although axes were the predominant tool form. In contrast to what was found in the settlements, the majority of basalt tools at Cova da Moura were finished and unused. This suggests that those basalt tools destined for Cova da Moura were either made at sites other than the settlements studied, or they were made specifically at the time of death of an individual, or they were taken away when the settlements were abandoned.

At Algar do Bom Santo, however, there are no tools made from basalt. The striking contrast in the use of this raw material from Cova da Moura is significant, I would argue. The two sites are quite close to each other in location and chronology, so there is little to explain the differences in other than ideological or social terms. It is possible that the choice of raw materials for polished stone tools to accompany the dead was very much based on the particular social or symbolic associations of the tool with the individuals being buried or offering the tool. More analyses of neighboring and contemporary burial sites would need to be carried out in order to confirm this hypothesis.

\section{Amphibolite}

Amphibolite is a mafic metamorphic rock, which is dark-green to dark-grey in color. Amphibolite outcrops are found in western and southeastern Iberia. Many of the amphibolites in western Iberia were formed during the Hercynian Orogeny, which occurred in the late Paleozoic era in Europe, throughout the Carboniferous to Permian (340-230 mya) (Ribeiro et alii, 1990). Sources that were used by the inhabitants of the study sites seem to have been primarily located in the Ossa Morena Metavolcanic Zone, approximately $150 \mathrm{~km}$ from the sites (Lillios, 1997; Read et alii, 1997) (Fig. 1).

What is immediately striking about amphibolite is that, despite its exotic source (relative to the five sites), it was the predominant raw material used to make the polished stone tools found at the three settlements. Its preference as a raw material for working tools on settlements is likely due to the stone's foliation, which when oriented parallel to the sides of the tools, imparts great strength to these tools against stresses transmitted along it. Amphibolite, in comparison to the other massive igneous rocks, such as basalt and dolerite, and the softer siltstone, is the most durable raw material that seemed to have been available to these communities.

Occasionally, unfinished amphibolite tools are found in the settlements. That some amphibolite tools were unfinished suggests that amphibolite was acquired, at times at least, in the form of roughouts. Whether these roughouts arrived at the settlements as the result of direct quarrying of the source materials by individuals who lived at the three settlements, or were acquired through intermediaries, is unclear.

Very rarely are finished and unused amphibolite tools found at the three settlements. This suggests that either tools went from their roughout phase to a tool put to use over a short period of time, or that

T. P., 57, n. ${ }^{\circ} 1,2000$ 


\begin{tabular}{|l|l|l|l|}
\hline & Amphibolites & Nonamphibolites & p-Value \\
\hline Leceia & $19 / 266$ & $1 / 74$ & 0.0614 \\
& $(7)$ & $(1)$ & \\
Zambujal & $46 / 375$ & $11 / 143$ & 0.1362 \\
& $(12)$ & $(8)$ & \\
Pragança & $8 / 206$ & $0 / 166$ & 0.0103 \\
& $(4)$ & $(0)$ & \\
\hline
\end{tabular}

Tab. 2. Rejuvenated tools from settlements. This table summarizes the count and percentages of rejuvenated tools (amphibolite vs. nonamphibolite) by site: count/total (\% of total).

* Test of equality ot two population proportions.

the inhabitants of the settlements took these unfinished/unused tools with them when they abandoned the site.

As finished and used tools, amphibolite tools were produced in a wide range of forms, such as axes, adzes, hammers, wedges, chisels, gouges, and burnishers. As these tools are subject to a range of mechanical stresses, amphibolite was likely perceived, and functioned effectively, as a versatile raw material by late prehistoric craftsmen. This is consistent with the overall preference of amphibolite over other raw materials, as discussed above.

Amphibolite tools found in the settlements were often rejuvenated. In fact, amphibolite tools are rejuvenated at a significantly higher rate than tools made from the other, largely local, raw materials (Tabl. 2). Its exotic source and value as a highly versatile and durable raw material seem to have encouraged ancient users of these tools to rework them into hammers, chisels, or gouges. For example, if a tool (such as an axe, adze, or hammer) had split down the middle, the broken halves were sometimes turned 90 degrees on their side and made into chisels or gouges. Most often, it appears that dulled axes and adzes were turned into hammers, probably once it was perceived that sharpening the working edges was no longer possible or that it would not produce a viable cutting tool. In summary, therefore, amphibolite roughouts or tools, once they arrived at the settlements, were employed in a wide variety of activities and likely had long use lives.

The presence of amphibolite tools in the burial sites is quite irregular. At Algar do Bom Santo, most of the polished stone tools were made on amphibolite, and amphibolite tools at this site were almost always found unused. At Cova da Moura, however, there is only one amphibolite tool, and it was used. The markedly different uses of amphibolite at these two sites is striking and may indicate that an amphibolite tool had a particular symbolic or social significance that deemed it appropriate as a burial offering under very specific conditions. More will be said about this below.

\section{DISCUSSION}

At these five sites, the life histories of stone tools, by raw material (Tabl. 3), do indeed seem to be patterned. Some raw materials, such as amphibolites and basalts, were used for a variety of tool types, while other raw materials were more specialized in their functions -when dolerite was selected, it was generally used to make hammers, and siltstone, when used, to make adzes. As a whole, tools made from locally available rocks, such as dolerite and basalt, were rarely rejuvenated, probably because it was relatively easy to acquire a new tool of these materials when one wore out. The exception to this pattern are the tools made of siltstone, which although available locally, were never rejuvenated. The explanation for this may be that the production and working of siltstone tools was a specialized activity, carried out at other sites than those studied here. The evidence seems to suggest this, as siltstone tools are never found as blanks at the sites and were generally made into only one form of tool - adzes.

Tools made of certain stones, such as amphibolite, were regularly rejuvenated and recycled and appear to have experienced a use-life significantly longer than tools made from other raw materials,

\begin{tabular}{|lllll|}
\hline Raw Material & amphibolite & basalt & dolerite & siltstone \\
Source/s & non-local & local & local & local \\
How acquired & some as blanks & some as blanks & some as blanks & finished tools \\
Tool Forms & all forms & all forms & most hammers & most adzes \\
Rejuvenated? & often rejuvenated & rarely rejuvenated & rarely rejuvenated & never rejuvenated \\
Context/s deposited & settlements (used) & settlements (used) & settlements (used) & settlements (used) \\
& burials (unused) & burials (unused) & & \\
& & & & \\
\end{tabular}

Tab. 3. Summary of life histories of stone tools, by raw material. 
such as basalt, dolerite, and siltstone. It is likely that the longer use-life of amphibolite tools was both a product of the value of the raw material as well as a factor that enhanced the value of the tools (and further encouraged their reuse).

In considering amphibolite (and indeed all raw materials), it is important to recognize not only the geographic location of the sources, but also to reflect on the possible social significance of the source areas. And for amphibolite, the source area in the Alentejo province of Portugal can be seen as a landscape where the dead are highly visible. In this region, hundreds of megaliths, many within walking distance to amphibolite outcrops, were catalogued by Georg and Vera Leisner (1943; Leisner, 1965) between the 1930s and 1960s. The Alentejo, in fact, boasts one of the largest megalithic monuments in Europe, the Anta Grande de Zambujeiro. These megalithic burials of upland Portugal were used throughout the Middle-Late Neolithic and Chalcolithic; thus, some predate the settlements of Zambujal, Leceia, and Pragança (Gilman, 1992). That the uplands and lowlands were linked economically and, thus, socially, in the Chalcolithic is indicated not only by the presence of amphibolite tools in the lowlands, but also by slate from the uplands in lowland burial sites. Likewise, tools made from flint, whose sources are in the lowlands, are sometimes found in upland contexts.

Because of the proximity of amphibolite sources and megalithic burials, and the socioeconomic ties which linked the uplands and the lowlands, I have suggested that amphibolite, unlike the other raw materials available for making polished stone tools, may have been symbolically associated with the past, the dead, and ancestral origins for lowland communities (Lillios, 1999a). In order for individuals and groups during the Chalcolithic to maintain and demonstrate affiliations to that past, particularly in situations of social stress, they needed to keep amphibolite tools in the land of the living - recycled, reused, or otherwise visible. Their maintenance in the land of the living, as heirlooms or mnemonics for lineage histories, would have suited the needs of emerging elites, anxious to legitimate their claim to authority or prestige. Basalt, dolerites, and siltstones, with their local origins, did not fulfill these same functions.

Indeed, amphibolite tools may have come to serve as social mnemonics, objectifying memories, relationships, and events, much as nephrite jade tools functioned (and function, to this day) for the
Maori of New Zealand (Best, 1912; Riley, 1994). The geographic distance that amphibolite travelled before arriving at lowland settlements may have been linked to temporal or genealogical distance (Helms, 1988, 1993). In a period of emerging social inequalities, as was the Late Neolithic and Chalcolithic of Iberia, durable markers of enduring social difference would have been critical, particularly during periods of social stress and competition. When amphibolite tools were deposited in burials, as used or unused tools (such as at Algar do Bom Santo), elites may have been more secure in their status and did not need to constantly reaffirm their position in society by the display of valuable, exotic goods, like amphibolite axes.

\section{CONCLUSION}

The evidence from the five sites discussed suggests that late prehistoric communities approached polished stone tools from both materialist and idealist stances. Both the mechanical characteristics and the ideological associations of stones were considered in the manufacture, use, and disposal of stone tools. For example, stones with distinct physical properties were clearly recognized by ancient stone workers. The durability and versatility of amphibolite and basalt were put to good use in a wide range of tool types and dolerite's ruggedness was appreciated in the hammers that were made from it. Yet the 'litho-logic' of late prehistoric craftsmen was not entirely a function of a least-cost/ least-effort rationale. Basalts and dolerites, despite being locally available, were not the principal raw materials used to make polished stone tools destined for use in living contexts. Rather, amphibolite, whose nearest sources to lowland communities was approximately $150 \mathrm{~km}$ away, across the Tagus River, was this preferred raw material. Furthermore, the most available raw materials were often not those that were considered the most disposable in burials. Tools made from dolerite, for example, a locally available raw material, were rarely included as burial offerings. The reality of raw material selection, use, and disposal in late prehistoric Portugal was, indeed, a complex amalgam of ideological and material concerns.

Recognizing the biographies of objects -their 'birthplaces', their temporality, and their historicity- particularly in complex societies in which individuals and groups may have needed to reify an- 
cestral claims to authority, clearly demands greater attention by archaeologists. However, this biographical approach requires an integrated, holistic perspective to archaeological analysis -one which places on equal footing the technological and socio-cognitive concerns of ancient peoples. Sourcing studies which neglect to take into account the social or ideological landscape of raw material sources provide as impoverished a view of the archaeological record as socio-cognitive approaches which fail to seriously address the sophisticated technological knowledge, skills, and concerns of ancient peoples.

\section{ACKNOWLEDGEMENTS}

Funding for this research was provided by the National Science Foundation (SBR-9406658), the American Philosophical Society, and the Archaeological Institute of America Archaeology of Portugal Fund. I would also like to thank Francisco Alves, João Cardoso, Cidália Duarte, João Ludgero Gonçalves, Michael Kunst, Luis Raposo, and Hans-Peter Uerpmann for allowing me to study the collections that constituted the basis for this research.

\section{BIBLIOGRAPHY}

APPADURAI, A. (1986): "Introduction: commodities and the politics of value". In A. Appadurai (ed.): The Social Life of Things: Commodities in Cultural Perspective. Cambridge University Press. Cambridge: 3-63.

Belo, R.; Trindade, L. and da Veiga Ferreira, O. (1961): "Gruta da Cova da Moura". Comunicações dos Serviços Geológicos de Portugal, 45: 391-418.

Best, E. (1912): The Stone Implements of the Maori. New Zealand Dominion Museum Bulletin, 4. New Zealand Dominion Museum. Wellington.

Cardoso, J.L. (1982): O Castro de Leceia. Câmara Municipal de Oeiras. Oeiras.

- (1989): Leceia: Resultados das Escavações Realizadas 1983-1988. Câmara Municipal de Oeiras. Oeiras.

- (1994a): Leceia: 1981-1993: Escavações do Povoado Fortificado Pré-Histórico. Câmara Municipal de Oeiras. Oeiras.

- (1994b): "L'habitat chalcolithique fortifiée de Leceia". Les Dossiers de l'Archéologie, 198: 10-15.

Cardoso, J.L. and Soares, A.M. (1996): "Contribution d'une série de datations $14 \mathrm{C}$, provenant du site de Leceia (Oeiras, Portugal), a la chronologie absolue du
Néolithique et du Chalcolithique de l'Estremadura portugaise". Actes du Colloque de Périgueux 1995, Supplément a la Revue d'Archéométrie: 45-50.

Cardoso, J.L.; Soares, J. and Silva, C.T. (1983-1984): “O povoado calcolítico de Leceia (Oeiras)”. Clio/Arqueologia, 1: 41-68.

Carta Geológica de Portugal (1992): Serviços Geológicos de Portugal. Lisbon. Scale - 1:500,000.

Chapman, R. (1990): Emerging Complexity: The Later Prehistory of South-East Spain, Iberia, and the West Mediterranean. Cambridge University Press. Cambridge.

DuARTE, C. (1998): "Necrópole neolítica doAlgar do Bom Santo: contexto cronológico e espaço funerário". Revista Portuguesa de Arqueologia, 1(2): 107-118.

FONTES, J. (1955): "Estação eneolítica de Liceia". Revista de Guimarães, 65: 341-352.

FORENBAHER, S. (1998): "Production and exchange during the Portuguese Chalcolithic: the use of bifacial flaked stone industries". Trabajos de Prehistoria, 55(2): 55-71.

- (1999): Production and Exchange of Bifacial Flaked Stone Artifacts during the Portuguese Chalcolithic. B.A.R. International Series 756. Archaeopress. Oxford.

Gallay, G. and SpINDLER, K. (1970): “Archäologische und Antropologische Betrachtungen zu den NeolithischKupferzeitlichen Funden aus der Cova da Moura/Portugal". Madrider Mitteilungen, 1: 35-58.

Gilman, A. (1987): "Unequal development in copper age Iberia". In E.M. Brumfiel andT.K. Earle (eds.): Specialization, Exchange and Complex Societies. Cambridge University Press. Cambridge: 22-29.

- (1992): "Iberia". In R.W. Ehrich (ed.): Chronologies in Old World Archaeology. University of Chicago Press. Chicago: 238-256.

GonÇALVES, J.L.M. (1990-1992): “Olelas e Pragança: duas fortificações calcolíticas da Estremadura". O Arqueologo Português, 8/10: 31-40.

HARRISON, R.J. (1977): The Bell Beaker Cultures of Spain and Portugal. American School of Prehistoric Research, Bulletin 35, Peabody Museum, Harvard University. Cambridge, Massachusetts.

Helms, M.W. (1988): Ulysses'Sail: an Ethnographic Odyssey of Power, Knowledge, and Geographical Distance. Princeton University Press. Princeton, New Jersey.

- (1993): Craft and the Kingly Ideal: Art, Trade, and Power. University of Texas Press. Austin, Texas.

KopytofF, I. (1986): "The cultural biography of things: commoditization as process". In A. Appadurai (ed.): The Social Life of Things. Cambridge University Press. Cambridge: 64-91.

Kunst, M. (1987): Zambujal, Glockenbecher und kerbblattverzierte Keramik aus den Grabungen 1964 bis 1973. Madrider Beiträge 5, Zambujal, Teil 2, Mainz.

- (1993): "Mauern und Türme der Kupferzeit". In H. 
Schubart, A. Arbeiter, and S. Noack-Halc (eds.): Sternstunden derArchäologie: Funde in Portugal. MusterSchmidt Verlag. Göttingen: 47-67.

Kunst, M. and Trindade, L. (1990-1991): "Zur Besiedlungsgeschichte des Sizandrotals". Madrider Mitteilungen, 31: 34-82.

LEISNER, G. and LEISNER, V. (1943): Die Megalithgräber der Iberischen Halbinsel: Der Süden. Römisch-Germanische Forschungen, 17. Verlag Von Walter de Gruyter and Co. Berlin.

LeISNER, V. (1965): Die Megalithgräber der Iberischen Halbinsel: Der Westen. Madrider Forschungen, I, 3. Verlag Von Walter de Gruyter and Co. Berlin.

Lillios, K.T. (1997): "Amphibolite tools of the Portuguese Copper Age (3000-2000 BC): a geoarchaeological approach to prehistoric economics and symbolism". Geoarchaeology, 12(2): 137-163.

- (1999a): "Symbolic artifacts and spheres of meaning: groundstone tools from Copper Age Portugal". In J. Robb (ed.): Material Symbols: Culture and Economy in Prehistory. Center for Archaeological Investigations. Carbondale, Illinois: 173-187.

- (1999b): "Objects of memory: the ethnography and archaeology of heirlooms". Journal of Archaeological Method and Theory, 6(3): 235-262

LisBoA, I.M.G. (1985): "Meaning and messages: mapping style in the Iberian Chalcolithic". Archaeological Review from Cambridge, 4(2): 181-196.

Quesada, C. and Munha, J. (1990): "Metamorphism of the Ossa Morena zone". In R.D. Dallmeyer and E. Martínez García (eds.): Pre-Mesozoic Geology of Iberia. Springer-Verlag. New York: 314-321.

Rawson, J. (1993): "The ancestry of Chinese bronze vessels". In S. Lubar and W.D. Kingery (eds.): History from Things: Essays on Material Culture. Smithsonian Institution Press. Washington, DC: 51-73.
Read, C.; Grapes, R. and Lillios, K. (1997): Chemical Analyses and Petrography of Amphibolite Implements and Possible Source Rocks from Western Iberia. Analytical Facility Publication No. 20. Victoria University of Wellington Press. Wellington, New Zealand.

Ribeiro, A.; Pereira, E., and Dias, R. (1990): "Allochthonous sequences, structure on the northwest of the Iberian Peninsula". In R.D. Dalmeyer and E. Martínez García (eds.): Pre-Mesozoic Geology of Iberia. Springer-Verlag. New York: 221-236.

Ribeiro, C. (1878): Noticias de Algunos Estações e Monumentos Préhistóricos. Lisbon.

RILEY, M. (1994): Jade Treasures of the Maori. Viking Sevenseas, Ltd. Paraparaumu, New Zealand.

Sangmeister, E. and Schubart, H. (1981): Zambujal. Die Grabungen 1964 bis 1973. Phillip von Zabern. Mainz am Rhein.

SCHIFFER, M.B. (1976): Behavioral Archeology. Academic Press. New York.

SKEATES, R. (1995): "Animate objects: a biography of prehistoric 'axe-amulets' in the central Mediterranean region". Proceedings of the Prehistoric Society, 61: 279-301.

SpINDler, K. (1981): Cova da Moura. Madrider Beiträge, 7 .

UERPMANN, M. (1994): “A indústria da pedra lascada do Zambujal: algunos resultados". In M. Kunst (ed.): Origens, Estruturas e Relações das Culturas Calcolíticas da Península Ibérica. Trabalhos de Arqueologia, 7: 37-43.

VAlERA, A.C. (1997): O Castro de Santiago (Fornos de Algodres, Guarda): Aspectos da Calcolitização da Bacia do Alto Mondego. Câmara Municipal de Fornos de Algodres. Lisbon.

VASCONCELOS, J. Leite de (1917): "Archeologia liceense". O Arqueólogo Português, 22: 203-206.

T. P., 57, n. $^{\circ} 1,2000$ 